SISTEM PERAMALAN JUMLAH PERSEDIAAN MINUMAN

MENGGUNAKAN METODE MOVING AVERAGE

\title{
SKRIPSI
}

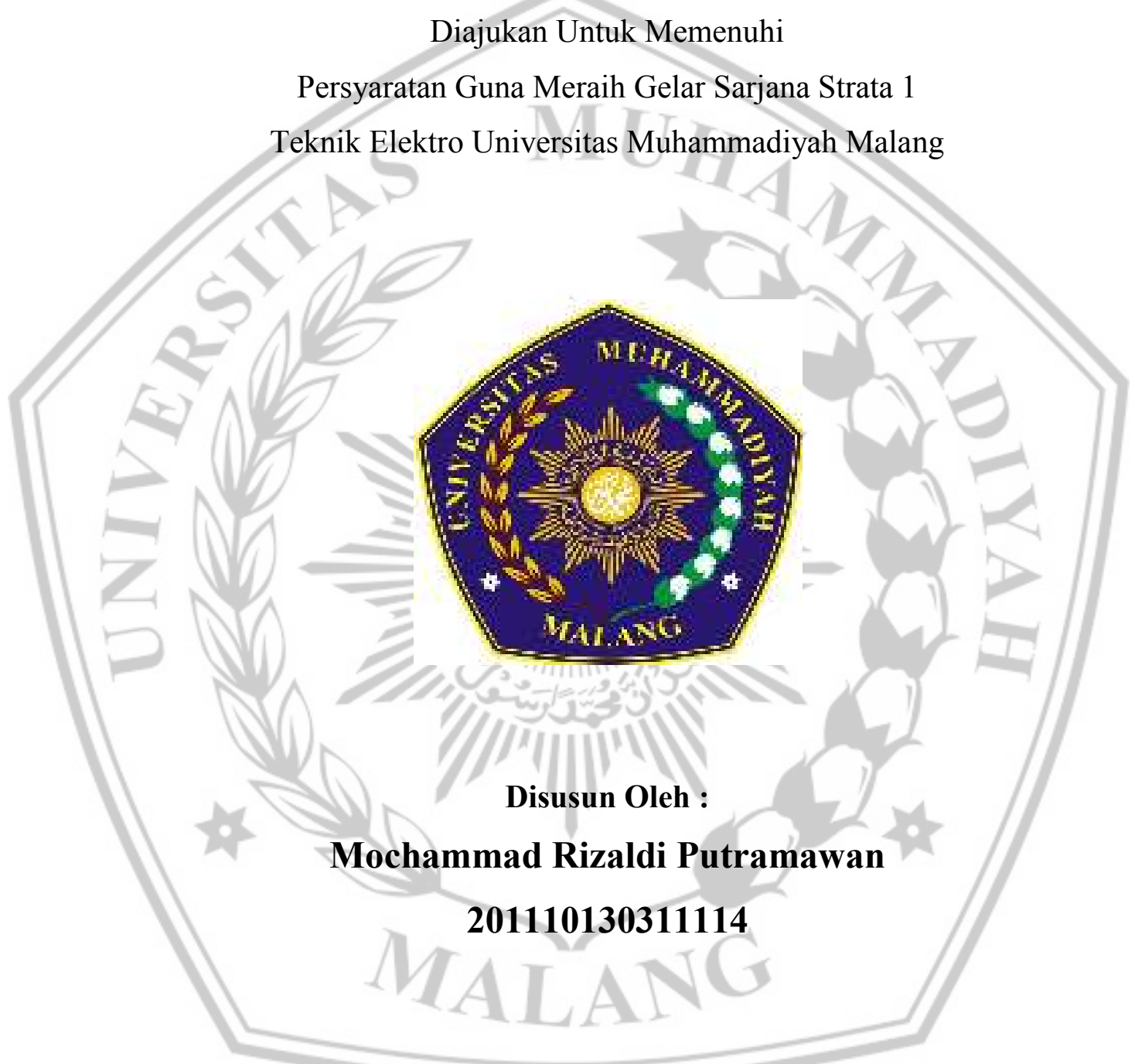

JURUSAN TEKNIK ELEKTRO

FAKULTAS TEKNIK

UNIVERSITAS MUHAMMADIYAH MALANG

2018 
LEMBAR PERSETUJUAN

\section{SISTEM PERAMALAN JUMLAH PERSEDIAAN MINUMAN MENGGUNAKAN METODE MOVING AVERAGE}

\section{SKRIPSI}

Diajukan Sebagai persyaratan Guna Meraih Gelar Sarjana Strata 1

Teknik Elektro Universitas Muhammadiyah Malang

Disusun Oleh:

Mochammad Rizaldi Putramawan

201110130311114

Malang, 28 juli 2018

Menyetujui,

Pembimbing 1

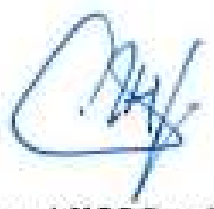

Ir. Nur Alif Mardiyah, MT.

NIDN: 0718036502

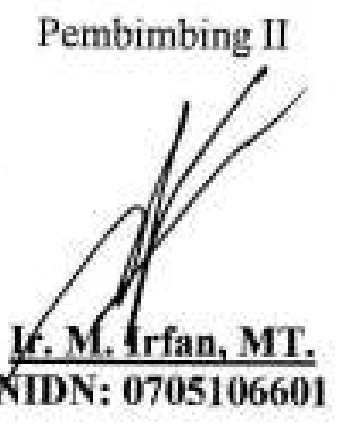


LEMBAR PENGESAHAN

\title{
SISTEM PERAMALAN JUMLAH PERSEDIAAN MINUMAN \\ MENGGUNAKAN METODE MOVING AVERAGE
}

\author{
SKRIPSI \\ Diajukan Sebagai Persyaratan Guna meraih Gelar Sarjana Strata (S1) \\ Teknik Elektro Universitas Muhammadiyah Malang \\ Disusun Oleh : \\ Mochammad Rizaldi Putramawan \\ 201110130311114 \\ Menyetujui,
}

Disetujui oleh

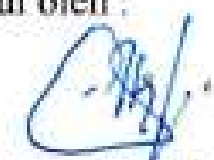

1. Ir. Nur Alif Mardivah, MT.

NIDN: 0718036502

( Pembimbing $\mathrm{I}$ )

2. Ir. M. $\mathrm{fan}, \mathrm{MT}$.

NIDN: 0705106601

(Pembimbing II)

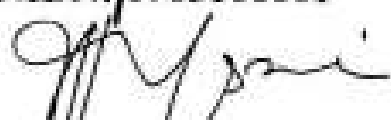

3. M Chasrnm Hasani, ST., MT.

NHDN: 0007086808

(Penguji I)

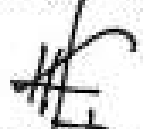

4. Khaeruddin, ST.

NIDN: 0718078603

(Penguji II)

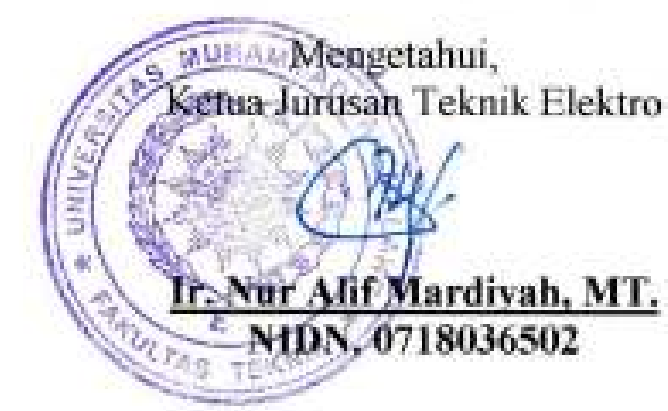




\section{LEMBAR PERNYATAAN}

Yang bertanda tangan dibwah ini :

$\begin{array}{ll}\text { NAMA } & : \text { Mochammad Rizaldi Putramawan } \\ \text { NIM } & : 201110130311114 \\ \text { FAK./JUR. } & : \text { TEKNIK/ELEKTRO }\end{array}$

Dengan ini saya menyatakan bahwa Tugas Akhir dengan judul SISTEM PERAMALAN JUMLAH PERSEDIAAN MINUMAN MENGGUNAKAN METODE MOVING AVERAGE beserta seluruh isinya adalah karya saya sendiri bukan merupakan karya tulis orang lain, baik sebagian maupun seluruhnya, kecuali dalam bentuk kutipan yang telah disebutkan sumbernya.

Demikian surat pernyataan ini saya buat dengan sebenar-benarnya. Apabila kemudian ditemukan adanya pelanggaran terhadap etika keilmuan dalam karya saya ini, atau ada klaim dari pihak lain terhadap keaslian karya saya ini maka saya siap menanggung segala bentuk resiko/sanksi yang berlaku.

Mengetahui,

Dosen Pembimbing
Malang, 28 juli 2018

Yang membuat pernyataan

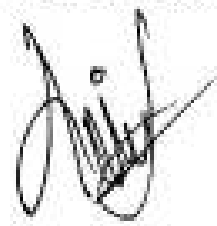

Mochammad Rizaldi Putramawan

NIM 201110130311114
Pembimbing I

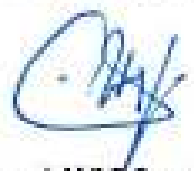

Ir. Nur Alif Mardiyah, MT.

NIDN: 0718036502

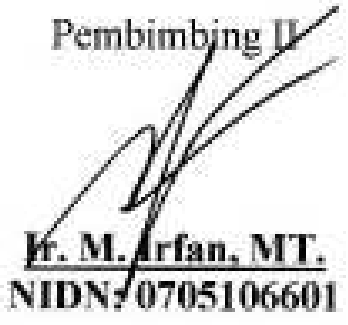




\section{PERNYATAAN ORISINALITAS}

Yang bertandatangan di bawah ini:

$\begin{array}{ll}\text { Nama } & \text { : Mochammad Rizaldi Putramawan } \\ \text { Tempat, tanggal lahir } & : \text { Tuban, 15 Juli } 1993 \\ \text { Nomor induk Mahasiswa } & : \text { 201110130311114 } \\ \text { Fakultas } & : \text { Teknik } \\ \text { Program Studi } & : \text { Elektro }\end{array}$

Menyatakan bahwa karya ilmiah (skripsi) dengan judul :

Sistem Peramalan Jumlah Persediaan Minuman Menggunakan Metode Moving Average

Adalah bukan karya tulis ilmiah (skripsi) orang lain, baik sebagian ataupun seluruhnya, kecuali dalam bentuk kutipan yang telah saya sebutkan sumbernya dengan benar.

Demikian surat pernyataan ini saya buat dengan sebenar - benarnya dan apabila pernyataan ini tidak benar, saya bersedia mendapatkan sanksi sesuai dengan ketentuan berlaku.

Malang, Sabtu 7 Maret 2020

Yang menyatakan,

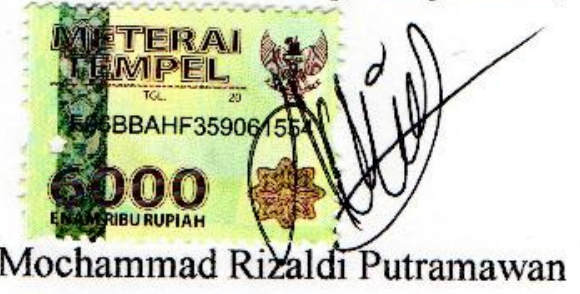




\section{KATA PENGANTAR}

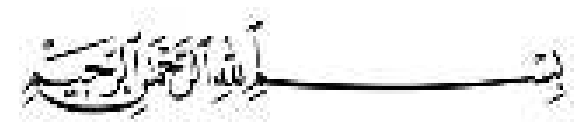

Segala puji bagi Allah SWT, yang telah memberikan Rahmat dan Karunianya, sehingga penulis dapat menyelesaikan skripsi yang berjudul:

\section{"SISTEM PERAMALAN JUMLAH PERSEDIAAN MINUMAN MENGGUNAKAN METODE MOVING AVERAGE"}

Tugas Akhir ini merupakan salah satu syarat studi yang harus ditempuh oleh seluruh mahasiswa Universitas Muhammadiyah Malang, guna menyelesaikan akhir studi pada jenjang program Strata (S1).

Peneliti menyadari masih banyak kekurangan dan keterbatasan dalam penulisan tugas akhir ini. Untuk itu, penulis sangat mengharapkan saran yang membangun agar tulisan ini dapat/berguna untuk perkembangan ilmu pengetahuan kedepan.

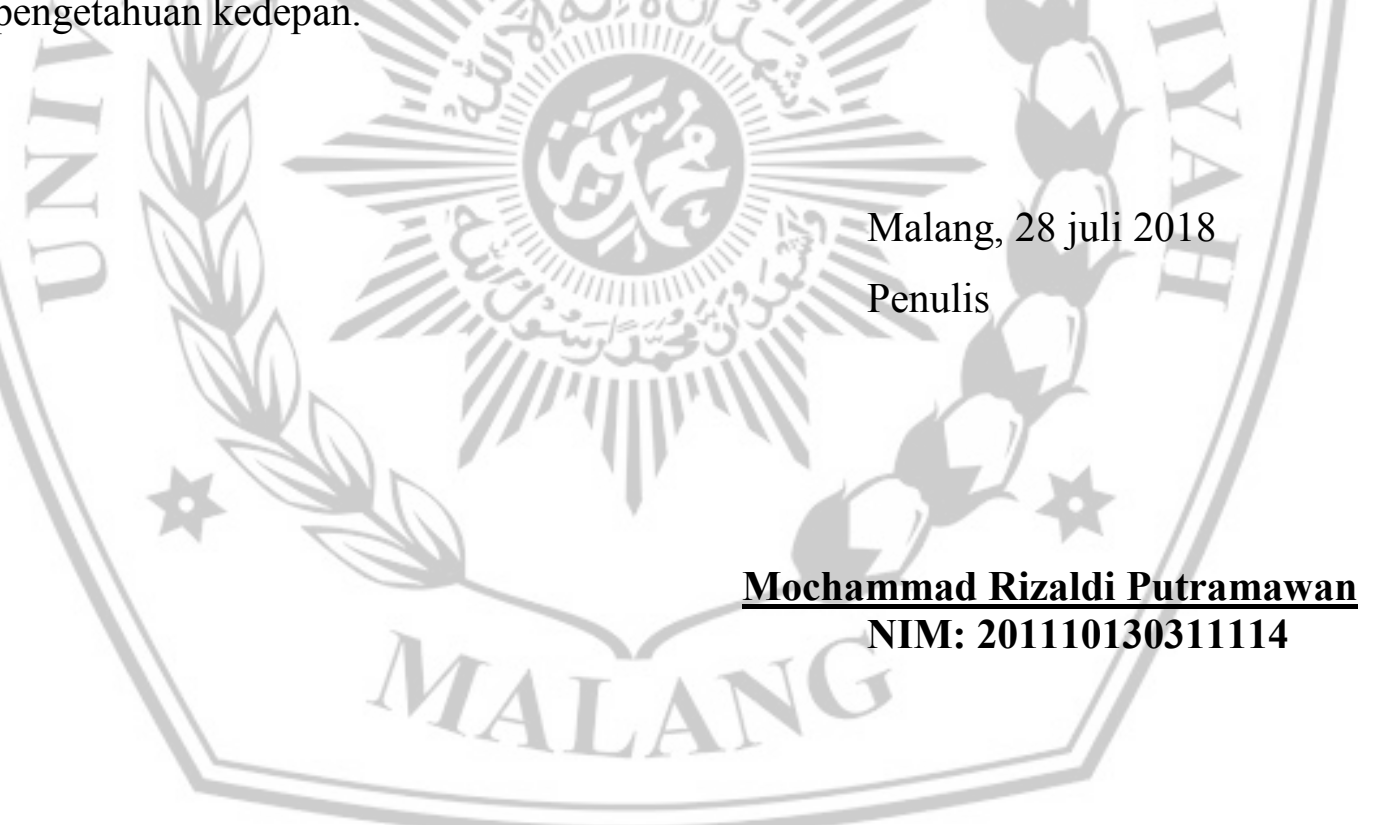




\section{DAFTRA ISI}

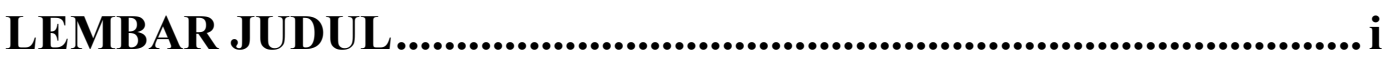

LEMBAR PERSETUJUAN ..........................................................ii

LEMBAH PENGESAHAN ..........................................................ii

LEMBAR PERNYATAAN ......................................................... iv

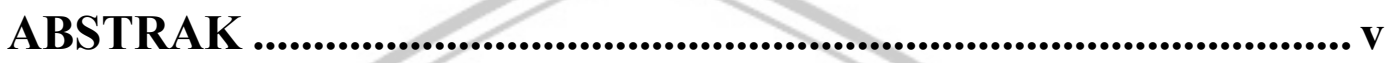

ABSTRACT .............................................................................

LEMBAR PERSEMBAHAN ......................................................vii

KATA PENGANTAR ..................................................................vviii

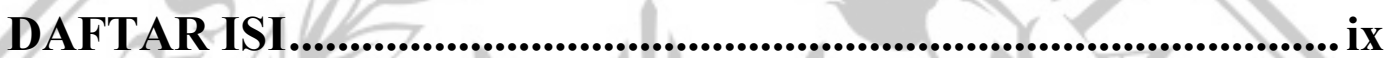

DAFTAR GAMBAR ........................................................... $x i$

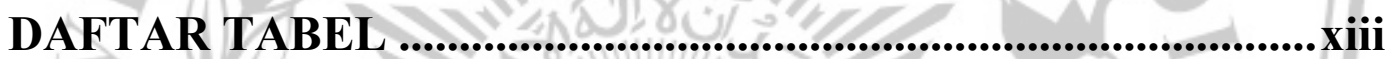

BAB I PENDAHULUAN

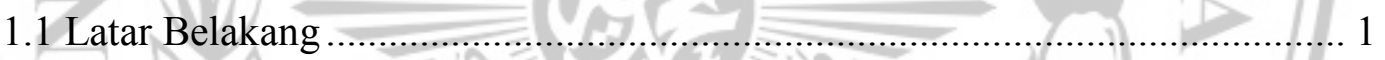

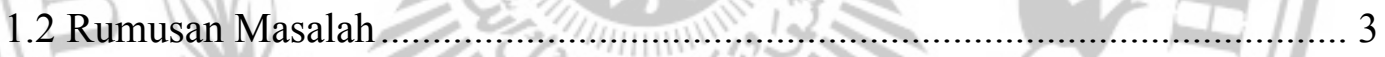

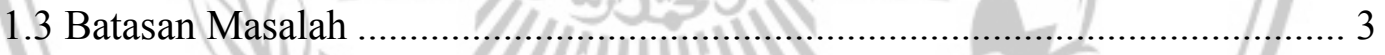

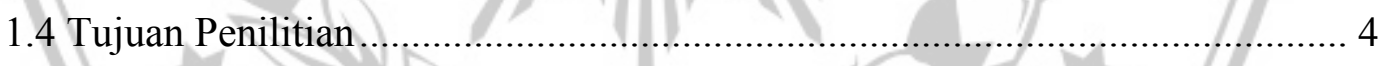

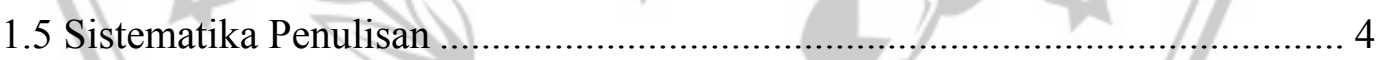

BAB II LANDASAN TEORI

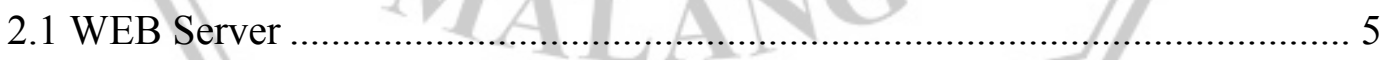

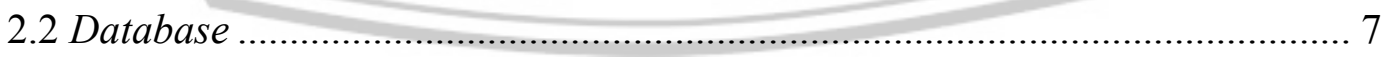

2.3 Konsep Dasar Forecasting ....................................................................... 9

2.4 Moving Average Forecasting ..................................................................... 10

\section{BAB III PERANCANGAN}

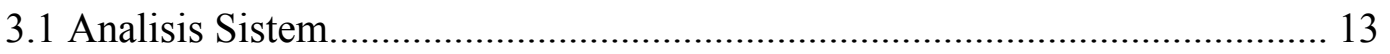

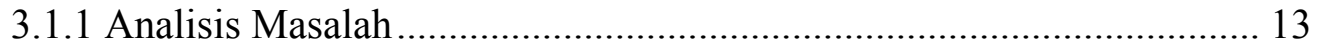


3.1.2 Gambaran Umum Sistem

3.1.3 Analisis Input dan Output ............................................................ 14

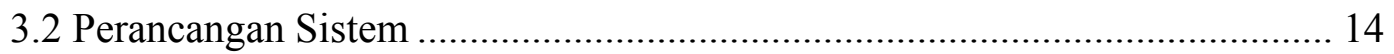

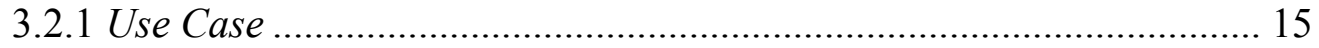

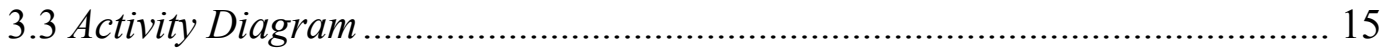

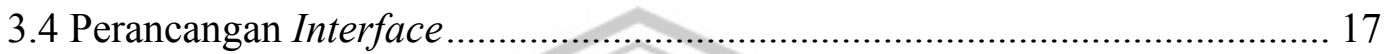

3.4.1 Halaman Login ................................................................... 17

3.4.2 Perancangan Interface Admin Persediaan ....................................... 17

\section{BAB IV IMPLEMENTASI DAN PENGUJIAN}

4.1 Pengguna Aplikasi Pada Sistem.......................................................... 20

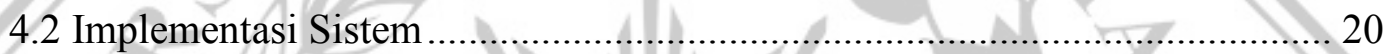

4.2.1 Halaman Login Admin........................................................... 20

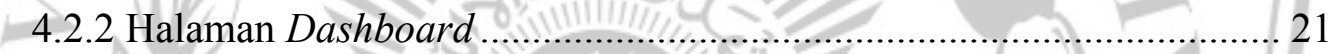

4.2.3 Halaman Nama Produk ........................................................... 22

4.2.4 Halaman Data Penjualan.......................................................... 24

4.2.5 Halaman Bahan Produk …......................................................... 27

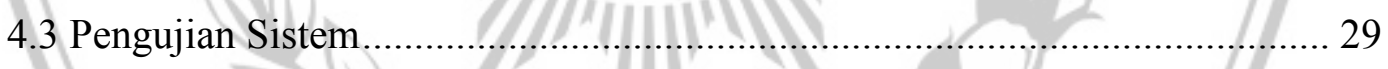

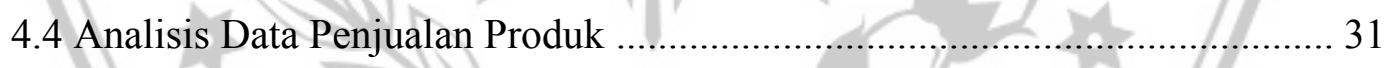

BAB V PENUTUP

DAFTAR PUSTAKA 


\section{DAFTAR GAMBAR}

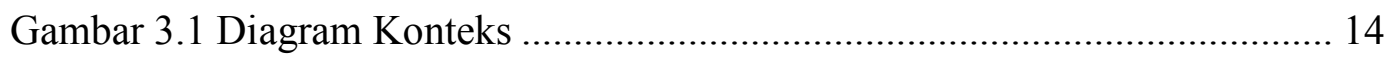

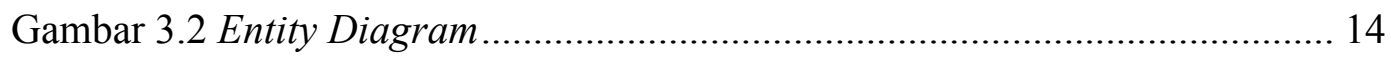

Gambar 3.3 Use Case .................................................................................... 15

Gambar 3.4 Activity Diagram Menambah Produk .......................................... 15

Gambar 3.5 Activity Diagram Memasukkan Data Penjualan ............................. 16

Gambar 3.6 Activity Diagram Menampilkan Data Prediksi ............................... 16

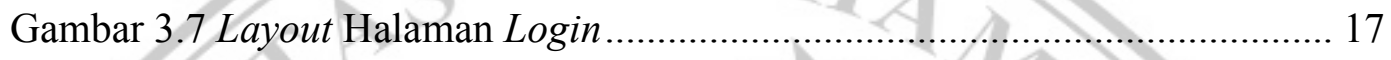

Gambar 3.8 Layout Halaman Utama / Beranda .............................................. 17

Gambar 3.9 Layout Halaman Daftar Barang ................................................. 18

Gambar 3.10 Layout Halaman Daftar Penjualan ............................................ 18

Gambar 3.11 Layout Halaman Peramalan .................................................... 19

Gambar 4.1 Tampilan Form Login Admin.................................................. 21

Gambar 4.2 Tampilan Halaman Dashboard ................................................. 21

Gambar 4.3 Halaman Utama Nama Produk,................................................. 22

Gambar 4.4 Form Menambah Produk ......................................................... 23

Gambar 4.5 Master Edit Data Nama Produk ................................................ 23

Gambar 4.6 Fitur Detail Peramalan Data Produk ............................................ 23

Gambar 4.7 Fitur Menghapus Produk............................................................ 24

Gambar 4.8 Halaman Data Penjualan Produk ................................................. 24

Gambar 4.9 Form masukkan Data Penjualan Produk........................................ 25

Gambar 4.10 Detail Data Penjualan.............................................................. 26

Gambar 4.11 Edit Data Penjualan ................................................................ 26

Gambar 4.12 Menghapus Data Penjualan ...................................................... 27

Gambar 4.13 Halaman Bahan Produk ............................................................... 27 
Gambar 4.14 Form Input Bahan

Gambar 4.15 Form Edit Bahan

Gambar 4.16 Halaman Detail Bahan

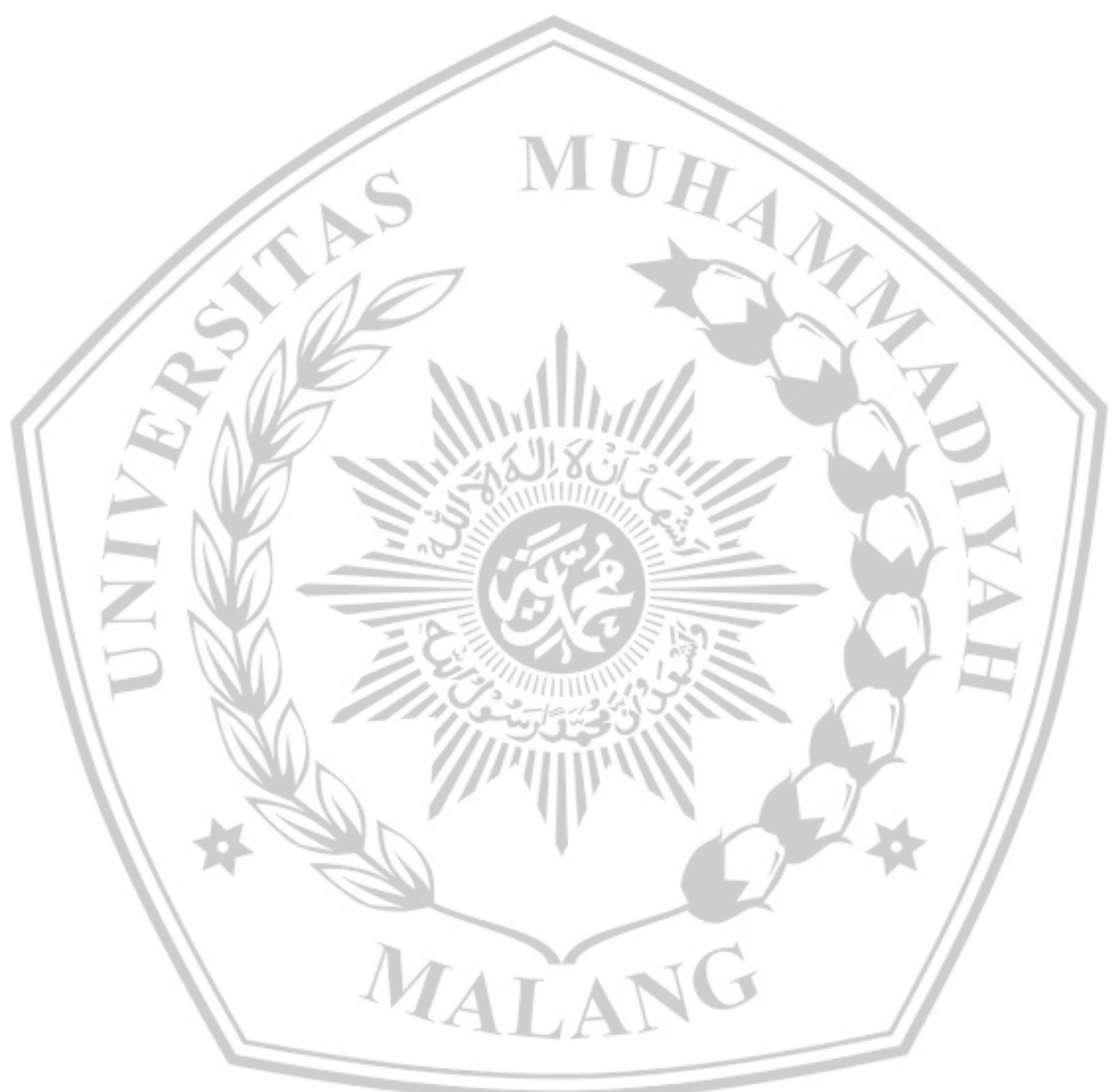




\section{DAFTAR TABEL}

Tabel 4.1 Hasil Pengujian 30

Tabel 4.2 Peramalan Penjualan Cappucino 31

Tabel 4.3 Data Ramalan, Sisa, dan Belanja Produk Bulan Juni 32

Tabel 4.4 Hasil Perhitungan Error Peramalan 33

Tabel 4.5 Hasil Perhitungan Rata Rata Error Produk dan Rata Rata Error Total 34

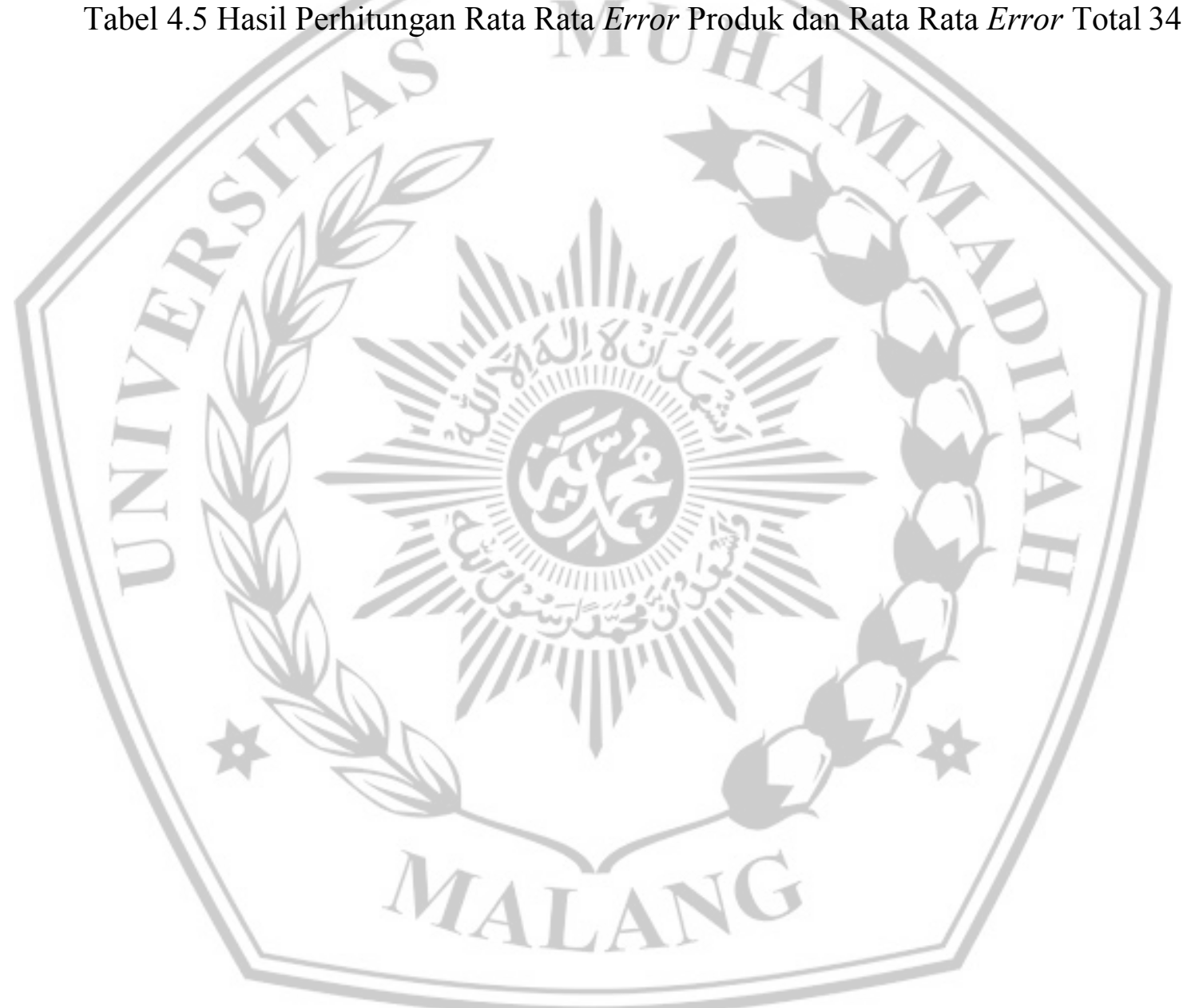




\section{DAFTAR PUSTAKA}

[1] A. Nurlifa, "Sistem Peramalan Jumlah Penjualan Menggunakan Metode Moving Average Pada Rumah Jilbab Zaky," JURNAL INOVTEK POLBENG, vol. 2, 2011.

[2] E. Herjanto, MANAJEMEN OPERASI, GRASINDO, 2003, p. 79.

[3] Montgomery, C. D. dan M. K. , Introduction to Time Series Analysis and Forecasting Second Edition, New Jersey: John Wiley \& Sons. Inc, 2015.

[4] M. Zainun, "Low Cost House Demand Predictor," Universitas Teknologi Malaysia, 2003.

[5] H. Diana, "Sistem Pendukung Keputusan Untuk Forecasting Penjualan di Toko Sumber Saudara," 2015.

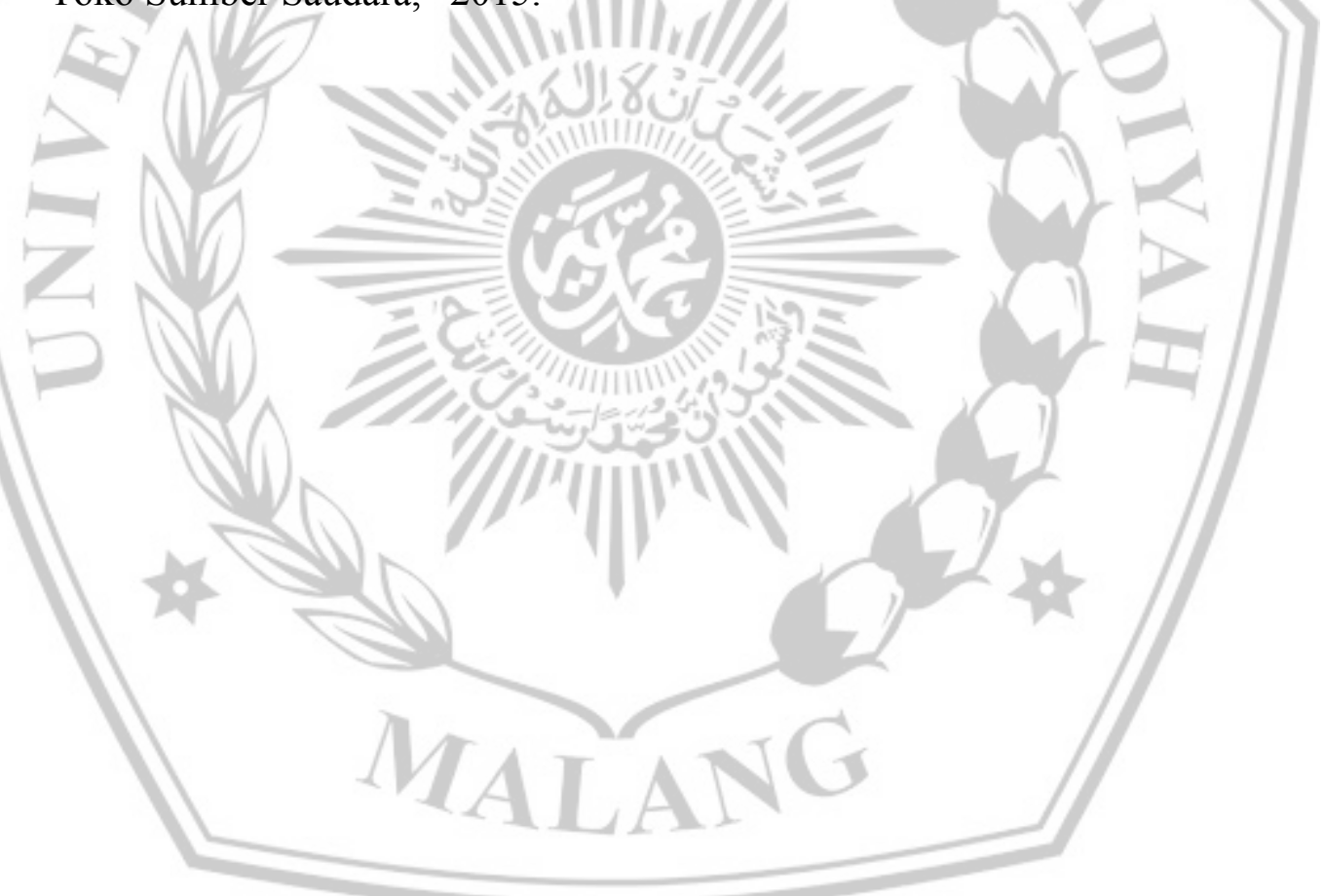




\section{UNIVERSITAS MUHAMMADIYAH MALANG FAKULTAS TEKNIK}

\section{JURUSAN TEKNIK ELEKTRO \& D3 TEKNIK ELEKTRONIKA}

J1. Raya Tlogomas 246 Malang 65144 Telp. 0341 - 464318 Ext. 129, Fax. 0341 - 460782

\section{FORM CEK PLAGIASI LAPORAN TUGAS AKHIR}

Nama Mahasiswa : Mochammad Rizaldi Putramawan

NIM

: 201110130311114

Judul TA

: SISTEM PERAMALAN JUMLAH PERSEDIAAN MINUMAN

MENGGUNAKAN METODE MOVING AVERAGE

Hasil Cek Plagiarisme dengan Turnitin

\begin{tabular}{|c|l|c|c|}
\hline No. & \multicolumn{1}{|c|}{ Komponen Pengecekan } & $\begin{array}{c}\text { Nilai Maksimal } \\
\text { Plagiasi (\%) }\end{array}$ & $\begin{array}{c}\text { Hasil Cek Plagiasi } \\
(\%)\end{array}$ \\
\hline 1. & Bab 1 - Pendahuluan & $10 \%$ & $7 \%$ \\
\hline 2. & Bab 2 - Studi Pustaka & $25 \%$ & $20 \% \checkmark$ \\
\hline 3. & Bab 3 - Metodelogi Penelitian & $35 \%$ & $24 \%$ \\
\hline 4. & Bab 4 - Pengujian dan Analisis & $15 \%$ & $10 \% \checkmark$ \\
\hline 5. & Bab 5 - Kesimpulan dan Saran & $5 \%$ & $0 \%$ \\
\hline 6. & Publikasi Tugas Akhir & $20 \%$ & $19 \%$ \\
\hline
\end{tabular}

Mengetahui,

Dosen Pembimbing I,

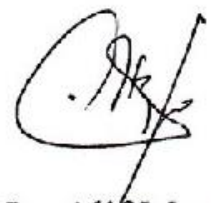

Ir. Nur Alyf Mardiyah, MT.

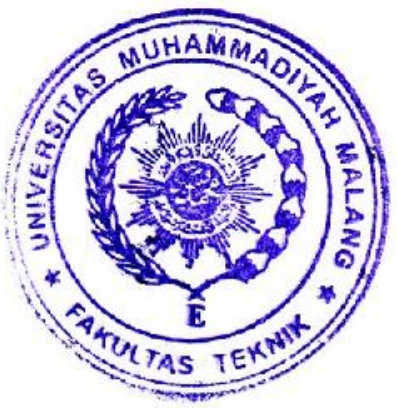

Dosen Pembimbing II,

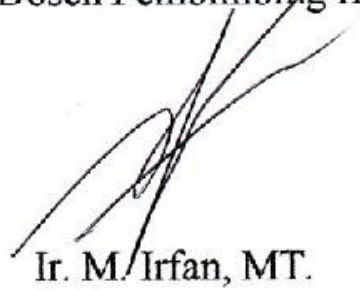

